\title{
POSSIBILITY OF RURAL SECTOR DEVELOPMENT IN SERBIA USING IPARD PROGRAM
}

\author{
Sladjana Gluscevic ${ }^{1}$, Sanja Maksimovic ${ }^{2}$, Radovan Pejanovic ${ }^{3}$, Teodor Simeunovic ${ }^{4}$
}

\section{Summary}

For the countries of the Western Balkans, especially in Serbia, whose economy is largely dependent on agriculture, strategically, within the accession negotiations with the European Union, topics concerning the rural sector are of great importance. In this sense, it is very important for all countries in the region, including Serbia to create the conditions for the implementation of IPARD - Instrument for Pre-Accession Assistance for Rural Development as the EU pre-accession program. This European instrument which helps countries that are at the door of the EU is actually a preparation for future participation in the complex and clearly defined Common agricultural policy of the European Union (CAP - Common agriculture policy), which is a set of rules equal for all and that means common agricultural budget. The importance of being well-prepared for the CAP, is expressed in the fact that this budget is more than half of EU cash. When a country joins the EU, it is given a quota in the common agricultural budget through two funds - EAFRD (European Agricultural Fund for Rural Development) and EAGF (European Agricultural Guarantee Fund), and for a national agriculture to effectively adopt the mode of operation of these instruments, it is important that the funds which are at its disposal in the pre-accession period are better utilized, and to master the principles on which CAP is based. First steps in the use of further more generous funds for agriculture and rural development are laid down through IPARD.

Key Words: IPARD program, rural sector, development, Republic of Serbia.

JEL: Q18, Q14, Q12.

1 Slađana Glušćević M.Sc., Agro Smart, Lasla Gala street no. 1, Novi Sad, Srbija, Phone: +381 63 500 525; E-mail: sladjana.gluscevic@dnevnik.rs.

2 Sanja Maksimović Ph.D., Assistant Professor, University Business Academy, Faculty of Law for Commerce and Judiciary, Geri Karolja street no. 1, Novi Sad, Serbia, Phone: +381 6583106 93, E-mail: sanja.m03@gmail.com.

3 Radovan Pejanović Ph.D., Full Professor, University of Novi Sad, Faculty of Agriculture, Zorana Đinđića street no. 1, Novi Sad, Serbia, Phone: +381 63600 217, E-mail: pejanovic@uns.ac.rs.

4 Teodor Simeunović Ph.D., Full Professor, High Agricultural School of Vocational Studies, Vojvodine Putnika street no. 56, Šabac, Serbia, Phone: +381 6692035 06, E-mail: vpssa@ptt.rs. 


\section{Introduction}

The main objective of the IPARD II program of the Republic of Serbia 2014-2020 is the improvement of the agricultural sector through competitiveness of agricultural products. For these purposes EU has devoted 175 million euros for our farmers, which will be available when Serbia overcomes administrative obstacles.

In order for a country to use funds from IPARD, two basic conditions - political and technicalneed to be fulfilled. Political condition implies that the country must be a candidate for membership in the EU and the other, technical condition, is that it must be able to manage these funds as required by Brussels, as applied in all Member States and candidate countries. Serbia became an EU candidate in March 2012 and met political condition but has not yet met the technical part of the criteria, i.e. it has not been accredited for the use of these funds. The reasons are many, but the most obvious is lack of adequate technical competence of the people to deal with the management of these funds in Serbia.

It is crucial for anyone who is engaged in agriculture in Serbia, that these funds are made available as soon as possible. There are several reasons for this, but the biggest is lack of budgetary resources to encourage the development of agriculture in Serbia and a need to increase the competitiveness of local agriculture to meet the open market competition (Pejanović, 2011).

It is also very important that these funds are largely focused on a specific group of future users - farmers, which are already big enough, so to speak, as they outgrow the national agricultural budget (domestic subsidies are insufficient to raise competitiveness), on the other hand, they are still too small for commercial bank loans. It is this group of farmers that has a great chance to draw funds from the IPARD maximum and improve their international competitiveness to a level necessary for successful market operations.

The interest of the country and the farmers and the entire rural sector is to promptly commence the training and the training of potential users. It is important for this education to take place on the terrain, as close as possible to the users. It is necessary to do everything possible in order to prepare better, as seen in the case of Croatia and other European countries benefiting from IPARD, a bad start and the initial outcome of a negative effect on the motivation of potential beneficiaries.

There are many values that IPARD brings in national agriculture support systems, and one of them is predictability and transparency of disbursement. Since the support to agricultural production in each country depends on the percentage of GDP growth and general progress of the national economy, consequently the agricultural budget is modified in line with current circumstances. Unlike the national funds that are most often determined annually and where the biggest problem is consistency of support, in case of IPARD funds budget is determined every seven years, within the EU budget period. This means that the amount and form of support almost never or very little change, allowing users long-term planning. When the amount of investment support is added to this, which can be substantial for individual measures, certainty and predictability are more than necessary (Gluščević, 2016). 


\section{Methodology and the sorces of data}

This work is a part of a research within the masters work of the first author, as well as additional researches of other authors. The method is, basically, descriptive. Based on a complexed analysis of the subject of the research, we have shown the mechanism of this important instrument of pre-accession assistance given by the European Union. We have also brought out the experiences of those countries that have gone through IPARD, esspecialy the experience of the Republic of Croatia. Starting from that point, we have come to the conclusion that there is a possibility of developing the rural sector in the Republic of Serbia using the IPARD programe. The source of data used in this work is the documentation of the EU and some other countries that are users, as well as other sources specified in the list of literature that was used. Besides this, methods of analysis and synthesis were used, induction and deduction, comparison, the statistic method of analysis.

\section{Establishing the Instrument for EU Pre-Accession Assisstance}

Instrument for Pre-Accession Assistance - IPA was established by the European Council in 2006. In this way, the European Commission has established a unique instrument for preaccession assistance to countries in the process of European integration for the budget period from 2007 to 2013 and then from 2014 to 2020. Components of IPA 2007-2013 were:

- Transition Assistance and Institution Building (IPA I);

- $\quad$ Cross-Border Cooperation (IPA II);

- $\quad$ Regional Development (IPA III);

- $\quad$ Human Resources Development (IPA IV) and

- Rural Development (IPA V).

Structure of IPA in the period of 2014-2020 differs from the previous ones; it is made of nine sectorial areas, including the Agriculture and Rural Development.

The EU Council on 17 July 2006 adopted Regulation (EC No 1085/2006), by which the instrument for pre-accession assistance was established. This instrument, passed on 1 January 2007, represented the legal basis for the provision of financial assistance to candidate countries and potential candidate countries in their efforts to strengthen political, economic and institutional reforms with regard to accession to the European Union.

The European Commission on 12 June 2007 adopted Regulation (EC No 718/2007) on the implementation of the IPA Regulation, precisely defining acceptable management and control provisions. IPA is one of the sources for financing of the EU, which, in accordance with EU budgetary policies, is created for a period of seven years. The total budget of IPA II for the period 2014-2020 amounts to 11.7 billion euros.

\section{The experience of the ten countries that have gone through IPARD} (EU members since 2004)

Before IPARD program in Croatia SAPARD program was implemented, which was related 
to a group of ten candidate countries, eight of which became members of the EU in May 2004. This is the first program of Community dedicated to the candidates, which was conducted entirely decentralized. This meant the previous accreditation bodies involved in the implementation and establishment of the system in the country where the aid is intended to ensure a transparent use of money from European funds.

All preceded the conclusion of the multi-annual financing agreement setting out the technical, legal and administrative framework for the implementation of the SAPARD program. With this EU sought to ensure, in the form of an international contract, that a candidate country (aid recipient) do whatever is necessary to protect the financial and other interests of the EU. This primarily meant the willingness of candidates to respect the strict rules of supervision and control, and that on their part they participate in co-financing the program.

The rule was that participation of candidates is a quarter of the total public support, which is different, depending on the types of measures. Public support has never been lower than 50 per cent of eligible costs. It is also the most common share of public support. SAPARD program had 15 available measures, and there were 13 measures listed in the programs of 11 candidate countries which were implemented until 2009.

The implementation of SAPARD program could not be started before the accredited bodies were involved in the implementation, and until the accreditation of measures contained in the program was made. Among these measures only the first two were accredited and applied in all 11 states, but their share of the total funds paid was 52 percent, or even 59 percent (excluding Romania). Only the Czech Republic and Slovakia (both ten measures) and Slovenia (five measures) managed to accredit for the duration of the program all that was envisaged in the plan. In none of the ten countries the approval of funds to beneficiaries was started before mid-2002.

States that became members in 2004 (EU-8: Czech Republic, Estonia, Hungary, Latvia, Lithuania, Poland, Slovakia, Slovenia) had little more than six years for the implementation (the end of 2006) and in the case of Bulgaria and Romania nine years (until the end of 2009) from the adoption of the plan. On the other hand, a one-year program SAPARD was available in Croatia for about three and a half years, after which the country was able to benefit from IPARD program.

The European Union, through SAPARD program, put approximately 3.12 billion euros at these countries disposal. Slightly more than half of that amount accounted for two least developed countries: Bulgaria and Romania. In the end, the sum of realized projects accounted at a little less than 32,000 for the EU-8 with the largest number of projects realized in Poland, as the largest country (slightly more than 71 percent in that group). In Bulgaria and Romania, which had a three-year longer period for implementation, about 7,000 projects were completed. The average value of completed projects in the two countries was nearly five times higher than the average value for the EU-8. The main reason is the increasing number of rural infrastructure projects, particularly in Romania, and for such projects more time is required (due to complex public procurement procedures carried out by local governments). 
The paper "Croatian experience with theSAPARD andIPARD: Review and Recommendations for neighboring countries in the region," Miroslav Bozic, who led the negotiating team for Croatian agriculture, it was concluded that every lap of enlargement of EU resulted in falling efficiency of the basic pre-accession program to help agriculture. For two main reasons: the first is less preparation of candidates, a second and perhaps more important is much more demanding procedure, which has already been stricter in the case of Bulgaria and Romania in the last years of the application. The true meaning of these stricter administrative procedures on the case of IPARD was experienced by Croatia, Macedonia and Turkey.(Bozic, 2012)

However, the total annual amount of funds that EU candidate countries have received in the pre-accession period was not negligible. They moved up to 193.3 million euros, which is how much Romania received annually. In this country, the average value of EU support per project amounted to 230,648 euros (Table 1).

Table 1 Implementation of SAPARD (IPARD) program in 10 new EU member states

\begin{tabular}{|c|c|c|c|c|c|c|c|c|c|}
\hline \multirow[t]{2}{*}{ Country } & \multicolumn{9}{|c|}{ Assets (in millions of euros) } \\
\hline & & 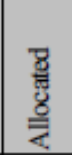 & & & & & 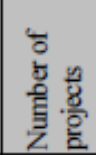 & & 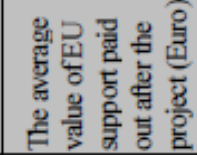 \\
\hline & $\begin{array}{l}\mathrm{Per} \\
\text { year }\end{array}$ & $\%$ & In total & $\%$ & Disbursed & & Paid & $\%$ & \\
\hline $\begin{array}{l}\text { 1.Czech } \\
\text { Republic }\end{array}$ & 30.9 & 4.3 & 92.8 & 3.2 & 92.8 & 100 & 1,495 & 3.8 & 62,059 \\
\hline 2. Estonia & 17.0 & 2.4 & 51.0 & 1.7 & 50.6 & 99 & 1,062 & 2.7 & 47,691 \\
\hline 3. Hungary & 53.3 & 7.5 & 160.0 & 5.4 & 160.0 & 100 & 2,575 & 6.6 & 62,121 \\
\hline 4. Latria & 30.6 & 4.3 & 91.9 & 3.1 & 87.3 & 95 & 1,702 & 4.4 & 51,286 \\
\hline 5. Lithuania & 41.8 & 5.9 & 125.4 & 4.3 & 125.3 & 100 & 827 & 2.1 & 151,558 \\
\hline 6. Poland & 236.5 & 33.2 & 709.4 & 24.1 & 708.7 & 100 & 22,775 & 58.6 & 31,116 \\
\hline 7. Slovalia & 25.6 & 3.6 & 76.9 & 2.6 & 76.9 & 100 & 893 & 2.3 & 86,119 \\
\hline 8. Slovenia & 8.9 & 1.2 & 26.7 & 0.9 & 26.6 & 100 & 559 & 1.4 & 47,672 \\
\hline Total EU 8 & 444.7 & 62.4 & 1.334 & $4 ., 4$ & $1,328.2$ & 100 & 31,888 & 82.1 & 41,653 \\
\hline 1. Bulgaria & 74.1 & 10.4 & 444.7 & 15.1 & 320.2 & 72 & 2,600 & 6,7 & 123,161 \\
\hline
\end{tabular}

\begin{tabular}{|l|l|l|l|l|l|l|l|l|l|}
\hline 2. Romania & 193.3 & 27.1 & 1,159 & 39.5 & $1,009.0$ & 87 & 4,374 & 11.3 & 230,648 \\
\hline Total EU2 & 267.4 & 37.6 & $1,604.5$ & 54.6 & $1,329.2$ & 83 & 6,974 & 17.9 & 190,598 \\
\hline \hline In total & 712.1 & 100 & $2,938.7$ & 100 & $2,657.5$ & 90 & 38,862 & 100 & 68,382 \\
\hline
\end{tabular}

Source: Author's calculations based on EU documents.

The experience of countries that used EU funds intended for rural development in the preaccession period shows that, later, as a member of the EU they have much more generous funds at their disposal. Romania, for example, as a candidate country, had 193.3 million 
euros available a year from SAPARD and IPARD programs, and after joining the EU Rural Development, the country was provided with 1.26 billion euros. Before Slovakia's accession to the EU, it received 25.6 million euros a year, but 285.2 million euros as a member (Table 2).

Table 2. Annual funding for rural development after joining the EU

\begin{tabular}{|c|c|c|c|}
\hline \multirow[t]{2}{*}{ Country } & \multicolumn{2}{|c|}{ Annual EU funds for rural development, in millions of euros } & \multirow[b]{2}{*}{$\mathrm{A} / \mathrm{B}$} \\
\hline & $\begin{array}{l}\text { A. After joining the EU } \\
\text { EAFRD }\end{array}$ & $\begin{array}{l}\text { B. Candidate } \\
\text { SAPARD/IPARD }\end{array}$ & \\
\hline Slovenia & $130,856,104$ & $8,883,586$ & 14.7 \\
\hline Czech Republic & $408,215,193$ & $30,929,235$ & 13.2 \\
\hline Croatia $^{5}$ & $333,000,000$ & $25,952,571$ & 12,8 \\
\hline Slovakia & $285,272,583$ & $25,638,615$ & 11.1 \\
\hline Hungary & $551,441,627$ & $53,346,376$ & 10.3 \\
\hline Poland & $1,914,132,594$ & $236,469,929$ & 8.1 \\
\hline Romania $^{6}$ & $1,269,406,054$ & $193,297,615$ & 6.6 \\
\hline Estonia & $103,390,979$ & $17,014,373$ & 6.1 \\
\hline Lithuania & $252,256,299$ & $41,816,078$ & 6.0 \\
\hline Bulgaria & $412,851,343$ & $74,124,833$ & 5.6 \\
\hline Latvia & $150,624,786$ & $30,627,834$ & 4.9 \\
\hline Total: EU-11 & $5,811,447,563$ & $738,101,045$ & 7.9 \\
\hline
\end{tabular}

Source: Author's calculations based on EU documents.

\section{The former finance agricultural projects in Serbia from European funds}

According to the IPARD program for 2014-2020, the main sources of EU funding agricultural projects in Serbia were the CARDS program and IPA funds. Serbia has received assistance under the IPA funds from the first two of the five components since 2007, and the first contracts were signed in 2010. Several IPA projects were aimed at capacity building and institutional preparation for IPARD:

- $\quad$ Project IPA 2007: “Capacity building for implementation of rural development policy in line with EU standards" (4.5 million euros), intended to strengthen the capacity and expertise of the agricultural payments and the Managing Authority;

- Technical assistance "Capacity building for the establishment and implementation of the LEADER initiative in Serbia."

The evaluation report of the Framework Agreement states that these results are only partially fulfilled. IPARD Agency has not been established, in accordance with EU requirements, while strengthening the capacity and expertise of the agricultural payments and the Managing Authority, and the LEADER approach, is only partially 
satisfied.

One of the projects that were related to the preparation of IPARD in our country: "Technical assistance in the evaluation of agriculture and rural development sector implemented and financed by IPA and other donors in the Republic of Serbia." Among others, there is a project IPA 2010 "System of accounting data on agricultural holdings (FADN)", with a budget of two million euros, which was supposed to improve the economic, financial and performance data on the Serbian farms. FADN (The Farm Accountancy Data Network) is the operational system established in 2015.

Among IPA projects that were related to agriculture are: "Harmonization of national legislation in the field of registration and control of plant protection products with EU regulations and the application of new legislation", "Building and technical support for the restoration of viticulture and zoning system of geographical origin of the wine " and others.

\section{Adoption of a national program and complementary documents}

The adoption of national IPARD (II) program in Serbia was preceded by numerous documents representing the basis for making IPARD. Among others, in 2013, the Law on Incentives in Agriculture and Rural Development was passed ("Official Gazette of RS", No. 10/13), which defines the rural development measures. Also, the Ordinance on the determination of areas with difficult working conditions in agriculture was passed the same year ("Official Gazette of RS", No. 10/13) defining areas with difficult working conditions in agriculture for a period of three years.

In 2014, the Government of Serbia adopted the "Strategy for Agriculture and Rural Development of the Republic of Serbia 2014-2020" which gives a new view and objectives relevant to agriculture and rural development, as well as the main measures that will support the further development of the sector in the future. Amendments to the Law on Agriculture and Rural Development should also create conditions for the establishment of IPARD mechanisms, and create the necessary legal and institutional structures for this program. An important document that defines all other documents related to rural development and agriculture is a "National Program for Agriculture and Rural Development of the Republic of Serbia from 2015 to 2020. (NPRD) “. This program is an instrument for financial assistance in the field of rural development for the programming period 2015 to 2020, of course, for national funds. This is a document that is complementary to IPARD program and defines measures to support rural development in accordance with the current national legal regulations and requirements, and defining the criteria and elements of financial support. The most important thing is, relying on the Croatian experience, that there is no overlap in measures and potential users of IPARD. So, when you meet the requirements and can apply for NPRD, you cannot be registered to a competition for IPARD, and vice versa. Figuratively speaking, the one who has 20 cows and wants to invest in facilities, equipment or something else, can apply for IPARD as this is the minimum criterion in this program when it comes to aid for the production of milk, on the other hand, a person who has 19 cows does not fit in these frames but can only apply for assistance from the NPRD. Basically, the National Program for Agriculture and 
Rural Development has easier requirements for users and therefore covers a larger number of farmers, given that the IPARD is more demanding. In addition to this document, there is a "National Program for the Adoption of the Acquis (NPAA)" and the entire mentioned legislation is a system that ensures the presence of Serbian agriculture and rural development in European integrations.

Support measures under the NPRD are:

- $\quad$ investments in physical assets of agricultural holdings;

- diversification of the rural economy;

- investments in the improvement and development of rural infrastructure and services;

- transfer of knowledge and the development of advisory services;

- crops;

- beekeeping;

- environmental protection;

- rural development in forest areas;

- LEADER approach.

The conclusion is that some of these measures are consistent with measures of IPARD program, but they, as well as programs of local governments and APV, vary according to users, criteria, level of investment.

\section{Customized IPARD}

In the first stage of the approval of the national IPARD program in the Republic of Serbia there are three accredited dimensions. The fourth measure, which refers to the LEADER approach, has not been accredited as the system of local action groups has not been established. The fifth measure which applies to organic agriculture has not been approved either.

First phase:

- Investments in physical assets of agricultural holdings,

- Investments in processing and marketing of agricultural and fishery products,

- Investments in the diversification of activities and business development on the farm.

Second phase:

- Preparation and implementation of local action strategies - LEADER approach,

- Agro-ecological and climatic conditions - organic farming.

For all five measures of IPARD program funds are defined on an annual basis, as part of the budget cycle 2014-2020. years. European funds will be made available for investments in property holdings (first measure), the processing capacities and marketing (second measure), and the promotion of rural tourism and related services (third measure). The most valuable 
is the first, which refers to investment in physical assets of farmers. The total budget for it is $101,386,667$ euros.

For example, here is what will be funded as part of measures of IPARD II program. The investments covered by the first measure relate to the four sectors - the production of milk, meat, fruit and vegetables and other crops, namely cereals, oilseeds, sugar beet. Generally speaking, with the help of IPARD fund farmers who satisfy the conditions that will be defined more precisely when the first call is announced, they will be able to raise or renew stables, facilities for waste management, manure storage facilities, silos and warehouses for grains ... will be able to purchase equipment and machines, to invest in the production of energy from renewable sources ... Europe will pay 60 to 70 percent of the value of total investment. Namely, the minimum donation amount is 60 percent of total eligible costs, and if it comes to young farmers, younger than 40 years at the time of filing, refund will be 65 percent. But if such investments include the farmers in mountain areas, European aid can go up to 70 percent of the value of investments, a further 10 per cent can be allocated for investment in manure storage, which is important for environmental protection (treatment of hazardous waste materials as manufacturing products in accordance with the nitrates Directive (91/676 / EEC), which aims to reduce water pollution caused or induced by nitrates from agricultural sources and preventing further such pollution).

Farmers, owners of registered farms, who intend to invest in the sector of fruit, vegetables and other crops, will receive a refund, ie. the European donation worth at least 10,000 euros and a maximum of 700,000 euros. For those who have opted for investments in the sector of meat and milk the least amount of return is 15,000 euros, and the biggest one million euros. We should also note that the user can get maximum support of EUR 1.5 million from IPARD public assistance program.

The right to apply for the first measure of IPARD are farmers or groups of producers registered in the Register of agricultural holdings, both individuals or legal entities. In general, the eligible expenditures are related to the construction or reconstruction and equipment. Construction and reconstruction include the costs of purchasing ready-made components and parts (purchase and transport costs) and their installation, and the costs of works (materials, transport and works). The equipment includes the cost of purchasing, transportation and installation.

\section{Applying for IPARD}

The process for the user of IPARD fund - from signing the contract to a request for payment is as following:

First, users should invest their own funds in what they want to do, then end the investment, provided that all the accounts and VAT are paid in full. After that they submit a request for payment with the original accounts and other necessary documentation, followed by the process of checking the eligibility of requirements, and this includes on-site control and administrative processing of inspection results. After all this, a decision is made on payment, the money is paid to the users and another inspection is after five years. IPARD is realized on 
the principle of co-financing and the total investment assistance for the user is 50 percent to 75 percent of the total investment in the project. Customer participation is 30 to 50 percent, the European Union, ie. IPARD fund, giving a maximum of 75 percent of the total state support, a national co-financing, ie. the support of the state is 25 percent. When it comes to payment, request for payment shall be submitted after completion of the investment, and the deadline for payment is 60 days. Then the farmer gets a return of at least 50 percent of the value of the investment.

Therefore, it is necessary to provide the full amount of money needed for the realization of the investment. This means that the end user has to have a bank account with the funds necessary for the realization of the investment. When ready for the investment, he applies for the announced advertisement of IPARD agency. At this stage he is required to submit all necessary documentation required to even enter the approval process of the project. These are, usually, various documents of evidence of ownership or lease of land, evidence of identity, registration of farms and the like, mostly the same as application for to the national measures. However, apart from these general documents, a potential user is required to submit specific documentation, such as a business plan, which, in the case of construction and reconstruction of the building, must contain a precise list of works, ie. main and preliminary project, proof of compliance with the minimum national standards relating to animal health protection, human health, plant health, safety at work, depending on the type of investment.

\section{Projects approval}

After submission of all required documents, potential user enters the approval process of the project. After the project is approved, the user can start the investment, but must not deviate from his project that was attached when applying. Even the smallest change will be subject to the approval of the IPARD Agency, otherwise the potential user can be denied. After approval of the project, the beneficiary of IPARD funds signs a contract with the IPARD Agency, which clearly defines the rights and obligations of both parties including the right to appeal in cases where the user believes that his rights have been violated. On the other hand, the user is required to comply with the approved project and accept inspections sent to him by IPARD agency with the purpose to check the progress of the project during the period of the investment, the work or the duration of the investment in the period of five years. Very important is that every investment has a minimum shelf life, and that is five years. This means that the user is obliged, in this period of time, to keep the investment (not to sell the object or change its purpose, nor to dispose of the machines), and on the other side, he needs to reach EU standards, depending on the type of investment. Otherwise, the user is obliged to return all funds.

\section{Approving payments}

Once a project is approved, the user starts with investment activities, according to the approved project. Depending on the organization of IPARD Agency, he may, within a specified time or just during the call (this advertisement is different from the competition for approval of the project), to carry out the refund of spent funds in the amount of $50 \%$ of 
the investment (or in some cases, 55 - 60 percent, and to 75 percent). On this occasion, user submits all accounts, evidence of the payment of funds and other, thus proving the performed transaction. Refund will usually be carried out once all funds are invested, but in a more demanding investment the transaction can happen in phases, and therefore the refund can be in several stages. In the case of purchase of machinery there is a limit concerning the country of origin. This can only be machines that are originating from EU countries or special status EU (candidate countries, potential candidates, EEA countries and countries in the framework of the European Neighborhood Policy).

\section{User control}

User control is multiple. She / he will first be checked at the stage of granting users when he starts the investment / buys equipment for which he is applying. This is the so-called "zero control". In case he / she had already started an investment, the application for the IPARD funds will be rejected. Another control is carried out before the disbursement of funds, and the goal is to determine whether the investment is carried out in accordance with the proposed project. If not, refund request will be denied. Last control is performed after the realized investment and after business funds are paid to the user. This is the ex-post control, which aims to determine whether the investment is held and whether the standards of the EU have been achieved at the end of the investment. Controls can be exceptional, depending on the circumstances (fraud, irregularities, etc.). User is obliged to keep all the documentation from the time of conclusion of the contract until the expiry of five years from realized investments.

All investments are made on the principle of pre-financing, that is, it is essential that the approved project is completed with its own funds (or credit), and the payoff follows after the completion of the entire investment and determination of compliance with the standards of the investment itself.

So, for "IPAII 2014-2020" the field of "agriculture and rural development" there are special rules deriving from the IPA II targets, which means that this area supports a gradual harmonization with the acquis of the Common Agricultural Policy of EU. Therefore, they are funding activities which by their nature are similar to those defined under the European Agricultural Fund for Rural Development, available to member states of the EU. In fact, there is a tendency for the countries in the accession process to become ready to fully implement the rules that apply to members of the EU, so the management and control systems for this area are similar to those in the Member States.

\section{Conclusion and recommendation}

Using the IPARD program, significant opportunities for the development of rural sector of the Republic of Serbia are provided. This undoubtedly confirms the experience of countries that had been through the pre-accession phase to the European Union. Therefore, proper agency must be formed seriously and responsibly, which would not only be established, but also built and accredited. In that way, like other institutions, this institution would have a decisive importance for the operation and support of the development of agriculture, in particular 
the strengthening of its competitiveness on the path of European integration. Holders of agricultural policy must redefine their goals and methods of operation, especially in the direction of efficiency of the use of supplementary funding, originating from the designated funds, which is what IPARD program is about.

\section{Literature}

1. Agricultural and Rural Developoment Law (2013): Official Gazette No.10/2013.

2. Anufjev,A., Dasic, G. (2012): Comparative advantages of agricultural Serbia and sustainble development,. Orginal scientific article, Socioeconomica, Vol. 1, No. 2, pp. 143-154.

3. Bogdanovic, A. (2015): Politics of rural development in the European Union and Serbia, European Affairs Fund APV, Novi Sad.

4. Bozic, M. (2009): WTO and Croatian agriculture, Ministry of Agriculture and Forestry of the Republic of Croatia, Zagreb.

5. Bozic, M. (2012): Croatian experience with SAPARD and IPARD: review and recommendations for neighboring countries in the region.

6. Bozic, M., Gelo, R., Sever- Koren, A. (2002):Stabilization and association process and Croatian agricultural politics, Collection of articles HAZU, Zagreb.

7. Bozic, M., Gelo R., Sever-Koren A. (2003): Croatian agriculture and the EU: wich way foward? Sociology of villages, Zagreb.

8. Chamber of Commerce and Industry of Serbia (2014): 100 questions and answers about the European Union for the agriculturists, Belgrade.

9. Croatian model of direct payment in the program-financial 2015-2020 period, Ministry of Agriculture, Fisheries, and Rural Development, Zagreb.

10. Department for European integrations (2013): Efficiency evaluation of international development help in the Republic of Serbia by sectors.

11. Eu Rural Review no. 1 - The European Agricultural Fund for Rural Development, Directorate- General Agriculture and Rural Development, no. 1.

12. Glossary of the European integrations (2010): Direction for the European Integrations, Sarajevo.

13. Glušćević, S. (2016): Development possibilities of the rural sector in Serbia by using the IPARD fund assets, master dissertation, University of Novi Sad, UNESCO chair for entrepreneurial students.

14. IPARD guide for the users for measure 101 (2014): Agency for payments in agriculture, fishery, and rural development, Zagreb.

15. Ministry of Agriculture of the Republic of Croatia (2012): IPARD program of the Republic of Croatia, the Plan for agricurtural and rural development 2007-2013, Zagreb.

16. Ministry of Agriculture and Environmental Protection of the Republic of Serbia (2014): IPARD program of the Republic of Serbia for 2014-2020.

17. National Agricultural program from 2010 to 2013 (2010): ,The Official Gazette of RS“، No.83/10, Belgrade.

18. Network for Rural Development of Serbia(2010): Action plan for 2011-2015. Project 
„RuralNet- National network for rural development, instrument for participation of civil society organizations and promotion of a dialog with rural networks " financed by the European Union within the project „Strengthening dialogs between Serbian civil society organizations and the EU“ and support program to rural development, Ministry of Agriculture, Forestry and Water Resources of the Republic of Serbia.

19. Njegovan,Z., Pejanovic, R. (2009): Rural regionalization of AP of Vojvodina, Monograph, University of Novi Sad, Faculty of Agriculture, Novi Sad.

20. Pejanovic, R. (2013): Experiments from agrarian and rural economy, University of Novi Sad, Faculty of Agriculture, Novi Sad.

21. Pejanovic, R. (2009): Agricultural Economics- Development problems of Agriculture in the Republic of Serbia, pp. 5-23.

22. Pejanovic, R., Njegovan, Z. (2011): Rural development and local economic development of AP of Vojvodina, Monograph, University of Novi Sad, Faculty of Agriculture, Novi Sad.

23. Pejanovic, R., Radovic, G., Tomas, M., Maksimovic G., Krajinovic G., Jelic V. (2010): Agricultural budget as a form of financing agriculture in the Republic of Serbia, Contemporary agriculture, Serbian magazine for agricultural aciences, Vol. 59, No.12/2010, University of Novi Sad.

24. Pejovic A., Lazovic M, Miric O., Knezevic I. (2014): A Guide through IPA II 2014-2020, European Movement Serbia, Friedrich Ebert Stiftung, Belgrade.

25. Program outline of the Vojvodina development 2014-2020. (2013): AP of Vojvodina Government, Novi Sad.

26. Radulovic, D. (2015): Economical aspects of regional development in the European Union, European Affairs Fund APV, Novi Sad.

27. SEIO (2010): Regional Politics of the European Union, Belgrade.

28. Scientific society of economists of Serbia with the Academiy of Economic Studies and Faculty of Economics in Belgrade (2014): State and perspectives of economic-finance relations of Serbia and foreign countries, Belgrade.

29. Scientific society of economists of Serbia with the Academy of Economic Studies and Faculty of Economics in Belgrade (2014): Reforms and development, state, results and the beginning of negatiations between Serbia and the EU.

30. SEIO (2010): Regional politics of European Union, Belgrade.

31. Strategies of agricultural and rural development of the Republic of Serbia for 2014-2020 period (2014), „The Official Gazette of RS“, No. 85/14, Belgrade.

32. The Republic of Serbia Government (2013): The needs of the Republic of Serbia for International development help in 2014-2017 period, with projection until 2020.

33. Vig, Z. (2015): Procedures and legal aspects in the EU, Introduction to the history of European integrations and the EU law, European Affairs Fund APV, Novi Sad.

34. Zagreb Institute of Economy (2007): Joining the European Union: Expected economic accomplishments, Zagreb.

\section{Internet sources}

1. A partnership between Europe and famers, http://ec.europa.eu/cap-overview/2014 
en.pdf

2. European Commission - General Directorate for Agriculture and Rural Development (2012): Rural development in the EU, Statistical and economic information report 2012, Brussels. http://ec.europa.eu/agriculture/statistic/rural-development/index_en.htm

3. European Commission - General Directorate for Agriculture and Rural Development (2007): Rural development in the EU, Statistical and economic information report 2007, Brussels. http://ec.europa.eu/agriculture/statistic/rural-developmentindex en.htm

4. European Parlament (2013): Regulation (EU) No.1299/2013 of the European Parlament and of the Concil on specific provisions for the support from the European Regional Development Fund to the European territorial cooperation goal. http://eur-lex.europa.eu/ legal-content/EN/TXT/?uri=celex\%3A32013R1299

5. European Parliment (2014):Commission implementing regulation (EU) No. 447/2014, on the specific rules for implementing Regulation (EU) No. 231/2014 of the European Parlament and of the Council estabilishing an instrument for Pre-accession assistance (IPA II). http://ec.europa.eu/enlargement/pdf/financial assistance/ipa/2014/20140502commission-implementing-reg-on-ipa2 en.pdf

6. European Parliament (2014): Regulation (EU) No. 231/2014 of the European Parliament and of the Council establishing an instrument for Pre-accession Assistance (IOA II) 


\section{MOGUĆNOST RAZVOJA RURALNOG SEKTORA U SRBIJI KORIŠĆENJEM IPARD PROGRAMA}

\section{Slađana Glušćević ${ }^{5}$, Sanja Maksimovićc ${ }^{6}$, Radovan Pejanović7, Teodor Simeunović ${ }^{8}$}

\section{Rezime}

Za zemlje Zapadnog Balkana, posebno za Srbiju, čija je ekonomija u velikoj meri oslonjena na poljoprivredu, strateški su, u okviru pristupnih pregovora sa Evropskom unijom, bitne teme koje se odnose na ruralni sektor. U tom smislu od velikog je značaja za sve zemlje regiona, pa i Srbiju da stvore uslove za primenu IPARD-a - Instrumenta pretpristupne pomoći za ruralni razvoj (eng. Instrument for Pre-Accession in Rural Development) kao pretpristupnog programa EU. Ovaj instrument evropske pomoći zemljama koje su pred vratima EU zapravo je priprema za buduće učešće u kompleksnoj i jasno definisanoj Zajedničkoj agrarnoj politici Evropske unije (CAP - Common agriculture policy), koja predstavlja set pravila jednakih za sve i koja podrazumeva zajednički agrarni budžet. Koliko je važno valjano se pripremiti za CAP, najbolje govori podatak da taj budžet iznosi više od polovine ukupne kase EU. Kad država uđe u EU, dobija svoju kvotu u zajedničkom agrarnom budžetu, preko dva fonda - EAFRD (Evropski poljoprivredni fond za ruralni razvoj) i EAGF (Evropski poljoprivredni garancijski fond), a da bi nacionalna poljoprivreda efikasno usvojila način funkcionisanja tih instrumenata, važno je da fondove koji su joj na raspolaganju u pretpristupnom periodu što kvalitetnije iskoristi i savlada principe na kojima se zasniva CAP. Prvi koraci u korišćenju daljih, izdašnijih fondova namenjenih poljoprivredi i ruralnom razvoju prave se upravo kroz IPARD.

Ključne reči: IPARD program, ruralni sektor, razvoj, Republika Srbija.

5 Slađana Glušćević M.Sc., Agrosmart, Novi Sad, Ulica Lasla Gala br. 1, Novi Sad, Srbija, Telefon: +381 63500 525, E-mail: sladjana.gluscevic@,dnevnik.rs.

6 Docent, dr Sanja Maksimović, Univerzitet Privredna akademija, Pravni fakultet za privredu i pravosuđe, Keri Karolja 1., Novi Sad, Telefon: +381 6583106 93, E-mail: sanja.m03@,gmail.com.

7 Redovni profesor, dr Radovan Pejanović, Univerzitet u Novom Sadu, Poljoprivredni fakultet, Ulica Dr Zorana Đinđića br. 1, Srbija, Telefon: +381 63600 217, E-mail: pejanovic@uns.ac.rs.

8 Redovni profesor, dr Teodor Simeunović, Visoka poljoprivredna škola strukovnih studija, Ulica Vojvode Putnika br. 56, Šabac, Telefon: +381 6692035 06, E-mail: vpssa@ptt.rs.

EP 2017 (64) 2 (753-767) 